\title{
Emotions and Expressions of Emotion as a Didactic Guide as to How to Pray: Berakhot in the Aramaic Prayers of Qumran*
}

\section{Introduction}

More than 900 Dead Sea scrolls are our richest source of Jewish thought and prayers from the Second Temple period. The latter include numerous blessings, hymns and a collection of liturgies for special occasions, as well as individual prayers. These prayers, or prayer formulations, testify to a well-established liturgical practice that served the Yahad community as a pillar of their nonsacrificial worship. Before the Qumran discoveries, we had few Jewish prayer texts that could be definitively dated in the pre-medieval period.

\section{Studies about prayers at Qumran}

Now that 300 prayers, hymns and psalms in Hebrew are at our disposal, ${ }^{1}$ it is not surprising that numerous studies have been devoted to this genre of literature. ${ }^{2}$ Most of these have focussed on the communal Hebrew prayers and there are far fewer studies dedicated to individual prayers in Hebrew or Aramaic. Although studies have been done on some specific personal prayers in Aramaic, such as the prayers in the book of Tobit, the prayer of Levi in the Aramaic Levi Document and in Nabonidus, I believe that there is no general study about this particular Aramaic corpus in its entirety. Yet these prayers are very interesting in many respects. First, they are, on the whole, testimonies to private, individual expressions of supplications or thanksgiving, and secondly, they confirm the trend towards the standardization of private Aramaic prayers and their

\footnotetext{
* I wish to express my gratitude to my friend Mme Karin Nobbs, Bestion de Camboulas and to Professor Stefan Reif for their kind assistance with the English translation of this article.

1 Mostly published in DJD 11 + 19; see further an overview in Schuller, Prayer (2000), 29-31.

2 Various comparative analyses of the Hodayot, Berakhot and Shirat Ha-Olam have been done by E.G. Chazon, D.K. Falk, R.Z.D. Arnold, B. Nitzan, E. Schuller, S.C. Reif and others.
} 
formulas. Last, but not least, they are authentic testimonies to the linguistic situation before, around and shortly after Jesus's lifetime.

\section{Cult and prayers in the First and Second Temple periods}

While in the First Temple period the cult was organized mainly by priests, the destruction of the common cult centre in 586 BCE brought about a reconsideration of the cult during the Second Temple period, focusing more on the responsibility of the individual believer, when communal and individual prayers came to serve the exiled Israelites as a substitute for the Temple sacrifice.

With regard to Jewish traditions and the Temple worship other than sacrifices, it is possible that that hymns and psalms accompanied the cultic ritual from ancient times; communal liturgy certainly brought the religious community to areas around the Temple, but we have no knowledge about how "communal" that liturgy was, and how much the common people were involved in the public ceremonies, and we certainly cannot speak about formally recited prayer in the First Temple period.

The Babylonian Exile and the Second Temple period constitute a watershed for the reorganization and survival of Israelite worship with a shift from regular and institutional Temple worship, to a long time period without a Temple (Hos 3:4), later followed by its replacement with regular prayers - both communal and private - in study centres and prayer-houses.

Deprived of their Temple, the priestly circles enforced the idea that the presence of God, which came to be known as the Shekhinah, was not restricted to the cult centre in Jerusalem but that the divine presence emanated from the spiritual temple that was created through the community of faith. Thus, the Babylonian Exile brought about an intellectualization of the cultic ritual whereby liturgy and prayer came to serve as a substitute for bloody Temple sacrifices and, as result, gathered the community around "the sacrifices of the lips" (Hos 14:3). ${ }^{3}$ Thus, verbal worship fulfilled two roles: first, it made possible a discrete communication with Israel's God YHWH in a polytheist environment and, secondly, it reinforced the social and ideological structure of the exiled Hebrews as

3 The use of prayer as a substitute for sacrifice follows the message of "the offerings of our lips instead of bulls”, as stated in Hos 6:6 and confirmed in Hos 3:4; 14:3; Ps 50:5, 14; Prov 21:3; Isa 1:11-13, 17; Jer 7:22; Ps 51:17-19. 
a strong and special ethnic group. The prayers were seen as equivalent to the sacrifices and temple offerings, while the community itself, without the Temple, became Temple-like. ${ }^{4}$ Indeed, according to the Talmud, communal prayer served as a substitute for sacrifice from the time of the Babylonian exile (b. Ber. 26a-b). ${ }^{5}$

This equation (temple $=$ community) allowed the Jewish community from that period onwards to survive each challenging situation. The value of prayer is well documented in the writings from Qumran where the Yahad offers: "without the flesh] of burnt offerings and without the fats of sacrifice - the offerings and the free-will offering of the lips in compliance with the decree will be like the pleasant aroma [of justice and the perfection ....]" (4Q258 frag. 2 II, 4-5). ${ }^{6}$ The equation of the Yahad as the "Temple of Men" $\left(m q d \check{s}^{2} d m\right)^{7}$ is comparable to Paul's NT-Temple metaphor (1 Cor 3:16-17) and to sentiments in John (2:19-21) ${ }^{8}$.

\section{Individual prayer}

Besides communal prayers, private prayers became a substantial constituent of Jewish religious life. As against biblical precedents, individual prayers at Qumran are more common and the blessings and prayers observe a structured pattern. The function of an individual prayer is not primarily to substitute for sacrifice but to allow a direct appeal to God for intercession or mediation. ${ }^{9}$ Through prayer, people enter into communication with God. While communal prayers promote the religious identity of a group, the individual, private prayer serves to satisfy the personal needs of a particular person. Already from pre-exilic times, we are familiar with reports of individual prayers, sometimes with spontaneous outpourings in times of suffering or joy, or with formulations of supplication, praise and thanksgiving. Of course, the characteristics of those prayers are also

4 Cf. Schattner-Rieser, Foundation; for a critical analysis of the spiritual interpretation that the Qumran-Community as a temple consisted of men, see Dimant, 4QFlorilegium, 269-288.

5 Cf. Idelson, Liturgy, XVIII.

6 The translation is drawn from García Martinez/Tigchelaar, Dead Sea Scrolls, 523, for frag. 4Q258 frag. 2 II, 4-5; = 1QS VIII, 24-IX, 10); 1QS IX, 5; X, 6. The passage cited in the Rule of the Community is paralleled elsewhere, as in 4Q256 XVIII; 4Q258 VII, VIII; 4Q259 III, IV; 4Q260 I.

7 For a different interpretation of the idea of the Qumran-Community as a temple consisting of men, see Dimant, 4QFlorilegium, 269-288.

8 Cf. Gärtner, Temple; Hogeterp, Paul; Böttrich, Tempelmetaphorik, 411-425.

9 Cf. Lockyer, Prayers. 
known from other ancient cultures and from the epigraphic, pagan sources of the Ancient Near East (especially Mesopotamia and Syria). ${ }^{10}$

The example of the daily prayers of Daniel, particularly his prayers in special situations such as when he was condemned to death during the Babylonian Exile, shows the need for a personal, private prayer as a means of communicating with God. The individual prayers from Qumran are embodied in narratives that describe personal experiences in vivid words and images, thus inspiring other individuals in a similar situation, to identify themselves with the whole of that text. ${ }^{11}$

These pictures summarized in words also serve a pedagogic aim and help the individual who hears or reads those texts to express his own feelings, while teaching him also how to address prayers with the appropriate words, as framed within stereotyped formulas. Here we should emphasize the fact that the Aramaic prayers from Qumran also confirm the valuable and justified use of the Aramaic language as an authorized language of prayer. The individual worshipper not only enters into contact with God, but also enters into dialogue with God, who functions as a comprehensive interlocutor.

Praying three times a day "facing Jerusalem" seems to be a well-established feature from Persian times. The mentions in Dan 6:11 and Ps 55:18 of personal prayer three times a day indicate its validity for an individual in a private prayer and not its use as general communal worship. As R. Sarason, in his detailed survey, demonstrates with reference to the Community Rule, "communal prayer in the Dead Sea Scrolls serves a cultic function as a substitute for sacrifices (1QS 9:5)", ${ }^{12}$ constituting a communal Sitz im Leben, while private prayer is intended to effect a personal conversation with God. In this dialogue with God, one can express the deepest feelings and longings of one's soul. Indeed, the Talmud defines prayer as the service of the heart (b. Ta'an. 2a). Through history, these longings have taken shape, and have been framed into fixed patterns of blessings ( $\left.b^{e} r a k h o t\right)$, with some of them being practised on nearly all occasions, while other fixed liturgies were used at particularly prescribed times and seasons. But even if spontaneous, and not categorically set out, there is still something of a fixed form in which to frame prayers. It is not appropriate to approach the Almighty like an old friend, saying to him "Hello! I need your help" or "I

10 Such as the inscription of Zakkur that contains a hymn of thanksgiving for salvation (,Danklied“), or the Fekherye Inscription, which contains curse formulas and others.

11 A single glance at these images inspires the emotions that connect us with a person or a past episode [even if the narrative is a fiction] and helps us to express our own feeling in words. 12 Sarason, Prayer, 151-172, esp. 154. 
wish to thank you". There are rules and gestures to observe, in order to address the Almighty in a respectful way, and in this case the Aramaic prayers of Qumran preserve for us some guidelines.

\section{About the Aramaic individual prayers at Qumran}

Within the 120 Aramaic texts from Qumran there are about fifteen prayers. Mention is made of several other prayers, but the texts have not been preserved. ${ }^{13}$ These texts are without exception the private prayers of individuals and include petitionary, supplicatory, thanksgiving and dedicatory prayers. ${ }^{14}$

The prayers do not contain what may be regarded as sectarian elements and we can exclude an Essene origin. There are some dualistic elements in 4QTobit (4Q197-200), 4QTestament of Qahat (4Q542) and 4QVisions of Amram (4Q543548) that may easily be explained as Persian influence and as common dualistic notions. ${ }^{15}$ The language of composition is late but still has classical Imperial Aramaic in it, with orthographic adaptations, characteristic of the Hellenistic period, and is surely pre-Maccabean, ${ }^{16}$ with some parts even originating in the Babylonian Exile. The Genesis Apocryphon is written in a later Aramaic dialect, close to the one of Onqelos, but is still a first-century composition and a composite text containing parts of older layers. Be that as it may, the prayers are written in the common language of the Second Temple period: Aramaic.

The Qumran Aramaic prayers are inserted into narrative contexts and embedded in family scenes, describing very personal experiences, and they employ a large gamut of emotions, from sorrow to joy. Weeping is often associated with the prayers and expresses an emotional state of grief and sorrow, but there are cases in which weeping may also be a sign of strong and overwhelming joy: Abram weeps bitterly, tears running down his cheeks, after Sarah is taken away by Pharaoh, while in another text, outside the context of prayer, Abram weeps

13 Such as Noah's thanksgiving in 1QapGen XI, 12-14 and Abram's exorcism prayer to cure Pharaoh from the evil spirit in col. XI, 28-29.

14 We would have had even more specimens, if the books of Tobit and Enoch had been entirely preserved. G. Schelbert has noted that there were virtually no Aramaic prayers in the time of Jesus and that he knows only two from Qumran: Abraham's prayer in the Genesis Apocryphon and the prayer of Levi (see ABBA, 263).

15 As in the book of Tobit, where the evil spirit Asmodeus is opposed to the good angel Azaria, or the mention of the Sons of Light and the Sons of Darkness (bny nhwr $w b n y$ ḥšwk ${ }^{2}$ ) in the Visions of Amram (4Q548 frag. 1-2, II, 10-11).

16 Cf. Schattner-Rieser, Apport, 101-123. 
over Lot in 1Q20 22:5. In the book of Tobit tears flow in many instances: in Tob 7:6-7, Raguel is tearful when he weeps and blesses his nephew Tobiah; Raguel's wife Edna and Sarah weep when they hear that Tobit has gone blind. In Tob 7:16, Sarah weeps before her seventh marriage-ceremony with Tobias, and, in Tob 11:9, Hannah weeps when her son comes back. Again, in Tob 11:13, Tobit weeps tears of joy when pronouncing a blessing over his returned son. Weeping is part of the ritual, because when YHWH hears a person's weeping, he will accept their prayer, as expressed in Ps 6:9-10.

Prayers that are presented as the spontaneous outpourings of individuals intent on opening a dialogue with $\operatorname{God}^{17}$ offer help with the management of situations and emotions such as sadness, illness, injustice, trauma, anger, and with the exteriorization of positive emotions. Therefore, the prayers are often linked with the emotional reactions of weeping and crying. ${ }^{18}$

Although the Qumran prayers and benedictions are presented as spontaneous expressions, there is evidence that they follow a didactic aim, so that it becomes clear that the similarity of various formulas indicates a tendency towards standardization and uniformity through the fixing of prayer patterns.

The majority of the prayers are found in the book of Tobit and the Genesis Apocryphon which are among the longest Aramaic texts. We count nineteen prayers, including benedictions that mention some prayers:

1. 1QapGen [1Q20] VII, 20: Noah's blessing ${ }^{19}$

2. 1QapGen [1Q20] X, 1-8, 17: Noah's praise and blessing

3. 1QapGen [1Q20] XI, 12-13: Noah's praise and thanksgiving

4. 1QapGen [1Q20] XII, 17-19: Noah's blessing

5. 1QapGen [1Q20] XX, 11-16 Abram's complaint and prayer for mercy on behalf of Sarah

6. 1QapGen [1Q20] XX, 28-29: Abram's prayer for the healing of Pharaoh from affliction and illness

7. 1QapGen [1Q20] XXI, 2-4: Thanksgiving for all that God has offered to Abram

8. 1QapGen [1Q20] XXII, 16-17: Melkizedeq's blessing of Abra(ha)m

9. 1QapGen [1Q20] XXII, 32-34 Abram's complaint that he has no heirs

10. 4QpapTob ${ }^{\mathrm{a}}$ ar [4Q196] frag. 6, 6-6, 13: Sarah's prayer for death (= Tob 3:10-15)

11. 4QpapTob ${ }^{\mathrm{a}}$ ar [4Q196] frag. 17 II, 2-10 (= Tob 12:6-22): An instruction for a prayer of praise and thanksgiving

12. 4QpapTob ${ }^{\mathrm{a}}$ ar [4Q196] frag. 18, 1-15: Tobit's thanksgiving (= Tob 13:1-18)

17 These prayers are similar to the Mesopotamian shu-ila prayers; see Zgoll, Mensch, 121-140.

18 So also in the biblical prayers of Ezra 10:1; 1 Sam 2:10 (Hannah); Ps 126:1 and 2x in Jeremiah, Neh 1:4 (weeping, fasting, praying); Ps 69:11-14.

19 The blessing is introduced by the words "So I blessed the great Holy One ..." but the blessing itself is not preserved; similarly in the fragmentary col. 5, 23 and col. 7, 7, see Machiela, Dead Sea, 42 and 48. 
13. 4QpapTob ${ }^{\mathrm{a}}$ ar [4Q196] frag 43, 1: Tobit's praise and final blessing (= Tob 14:8)

14. 4QEn ${ }^{\mathrm{c}}$ ar [4Q204] frag. 111, 2: Henoch's praise and thanksgiving (= 1 En. 22:14)

15. 4QT. Levi ${ }^{\mathrm{b}}$ ar [4Q213a] frag. 1, 1-18 + 4Q213a frag. 2, 1-10: Prayer of Levi (restored on the basis of a single Greek text from Mount Athos and not included in the TXII)

16. $4 \mathrm{QPrNab}$ ar [4Q242] frag. 1-3, 1: Prayer of Nabonidus for his healing

17. 4QTQahat ar [4Q542] frag. 1 I, 1-3: Hymn of praise

18. 4 QPrEsther ${ }^{\mathrm{d}}$ ar $=4 \mathrm{Q}$ Legends of the Persian Court [4Q550c] frag. 1 I, 1-5: Prayer for the forgiveness of sins

19. 4QExorcism ar [4Q560] magic text or incantation text for exorcising evil and disease

I would now like to present a selection of prayers and benedictions that are representative of emotional states, and that share some common features. Let us first look at the emotional prayers in the Genesis Apocryphon and the book of Tobit, ${ }^{20}$ which are the longest Aramaic texts preserved in Qumran.

The Genesis Apocryphon consists of two different parts, a Noah-cycle and an Abra(ha)m-cycle, both of which contain a large gamut of prayers and benedictions describing emotional scenes in situations of sadness and lament, as well as of joy and thanksgiving. For some prayers and benedictions we have the texts themselves, while others are only mentioned. The prayer presented here has no counterpart in the Bible but is representative of prayers in the intertestamental literature and paralleled by other texts from Qumran in form and structure; they follow a common "model" and may be defined as didactic religious texts. The Deuterocanonical or Apocryphal book of Tobit is a religious novel of instruction and edification that offers manifold insights into Jewish faith and piety, combining prayers, psalms, and words of wisdom. Among these instructions are guidelines for the matrimonial model, as well as exemplars for prayers and benediction formulas. ${ }^{21}$ The book contains no less than six prayers, covering a wide gamut of emotional prayers from deepest sorrow, depression, and a longing for death, to great joy and praise. ${ }^{22}$

About $40 \%$ of the Aramaic text from Qumran is preserved, and the text corresponds to the long version in Codex Sinaiticus. ${ }^{23}$ Three of the prayers are pre-

20 4Q196 (3:5, 9-15, 17); 4Q197 (3:6-8); 4Q200 (3:3-4, 6, 10-11).

21 In Tob 6:17 and 12:6-10, the angel Raphael offers instruction about how to practise prayer.

22 Cf. Di Lella, Prayers, 95-115, esp. 95.

23 The Sinaiticus version is also known as Gr. II which is 1700 words longer than the shorter Gr. I. Among the Dead Sea Scrolls, five manuscripts have been discovered, four in Aramaic (4Q196-4Q199) and one in Hebrew (4Q200); for the existing versions of the book of Tobit in Greek see Di Lella, Prayers, 96. 
served among the Qumran fragments ${ }^{24}$ and they clearly correspond to the longer version known from Sinaiticus. The Aramaic is classical Imperial Aramaic with many Persian loan-words and archaisms of Imperial Aramaic. Even if the transcriptions are actually later, there is no doubt that the composition originates from the Persian period. ${ }^{25}$

In our second stage, let us take a look at the benediction formulas in the Genesis Apocryphon, the book of Tobit, Enoch and Qahat.

\subsection{Emotional prayers involving weeping in grief or joy}

\subsubsection{Abram's prayer on behalf of Sarai from 1 Q20 (1QapGen)}

After Pharaoh of Tanis learned about the beauty, he took her away to become his wife (1Q20 XX, 12-16). After this, Abram told the Egyptians that she was "only" his sister (and not that she was his wife) in order to save his own life. Therefore, Abram is in distress and prays for his wife's purity, for her not to be defiled.

\begin{tabular}{|c|c|}
\hline $1 Q 20 X X, 10-16$ & Abram's grief and prayer for the life of Sarai \\
\hline 10 ... ושביקת אנה אברם בדילהא ולא קטילת & \multirow{2}{*}{$\begin{array}{l}10 \text {... And I, Abram, was spared because of her. } \\
\text { I was not killed, and I wept }\end{array}$} \\
\hline ובכית אנה & \\
\hline 11 אברם בכי תקיף אנה ולוט בר אחי עמי בליליא & \multirow{2}{*}{$\begin{array}{l}11 \text { bitterly - I, Abram, and Lot, my nephew, } \\
\text { along with me on the night when Sarai was } \\
\text { taken from me by force. Vacat }\end{array}$} \\
\hline • באונס 』』 & \\
\hline 12 בליליא דן צלית ובעית ואתחננת ואמרת & ght I prayed, I entreated, and I asked \\
\hline באתעצבא ודמעי נחתן בריך אנתה אל עליון מר & for mercy. Throu \\
\hline לכול & d (are) you, O God Most \\
\hline 13 עלמים די אנתה מרה ושליט על כולא ובכול & ${ }_{13}$ ages! For you are Lord a \\
\hline מלכי ארעא אנתה שליט למעבד בכולהון דין וכען & $\begin{array}{l}\text { over all the kings of the eart } \\
\text { to enact judgement on all of }\end{array}$ \\
\hline 14 קבלתך מרי על פרעו צען מלך מצרין די דברת & ${ }_{14}$ I lodge my complaint with you, my Lord, \\
\hline אנתתי מני בתוקף עבד לי דין מנה ואחזי ידך & $\begin{array}{l}\text { against Pharaoh Zoan, the king of Egypt, } \\
\text { because my wife has been taken away from }\end{array}$ \\
\hline רבתא & $\begin{array}{l}\text { me by force. Do justice to her for me, and } \\
\text { show forth your great hand }\end{array}$ \\
\hline
\end{tabular}

24 With regard to Tob 6:8-18, the exorcism ritual for removing the evil spirit Asmodaeus who afflicted Sarah is described in 4Q196-4Q197; unfortunately the praise in 8:4-8 is not preserved among the Qumran manuscripts. For further reading, see Stuckenbruck, Book, 258-269. 25 Schattner-Rieser, Apport, 101-123, esp. 116-118. 
אנתתי מני וינְדעוך מרי די אנתה ואל ישלט בליליא דן לטמיא לכול מלכי

16 ארעא ובכית וחשית

בליליא דן שלח לה אל עליון רוח מכדש למכתשה ולכול אנש ביתה רוח

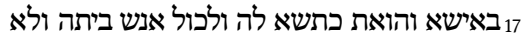

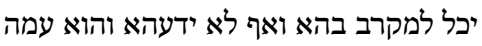

15 against him and against his entire household. May he not be able to defile my wife tonight - that it may be known about you, my Lord, that you are Lord of all the kings of 16 the earth." I wept and became silent.

That night God Most High sent him a pestilential spirit to afflict him and all the men of his house, a spirit ${ }_{17}$ of evil which kept afflicting him and all the men of his household, so that he was not able to approach her; nor did he have intercourse with her, though she was with him. ${ }^{26}$

\subsubsection{Sarah's prayer for death ${ }^{27}$}

The prayer of Sarah for death follows Tobit's prayer for death, which we present further only in a translated version, because we lack the Aramaic original in its entirety. Tobit, a pious Israelite deported to Nineveh in 721 BCE after the fall of the Northern kingdom of Israel, suffers severe reverses and becomes blind. Because of his misfortunes he begs the Lord to let him die. In Media, at this same time, a young woman, Sarah, also prays to die, because she has lost seven husbands, each killed in turn during the wedding night by the demon Asmodeus. God hears the prayers of Tobit and Sarah and rescues both of them from their distress.

\begin{tabular}{ll}
\hline 4Q196 Tob $^{\mathrm{a}}$ ar frag. 6, 2-13 & Sarah's grief and prayer for death: \\
(= Tob 3:9-15; and 4Q200 1II) & Tob 3:10-15
\end{tabular}

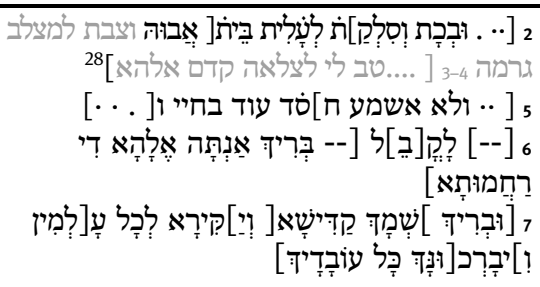

26 Fitzmyer, Genesis Apocryphon, 101.

27 Sarah's prayer has corresponding parts among the Hebrew fragments of Tobit from Qumran (4Q200) and is restored on the basis of the Greek text and the medieval Aramaic version.

28 Reconstructed with the medieval Aramaic medieval text in Gaster, Versions; and Weeks/ Gathercole/Stuckenbruck, Book, 123. 


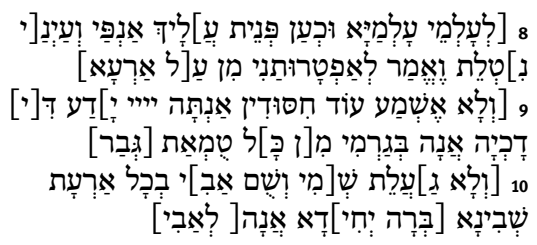

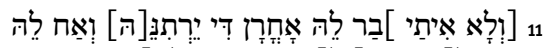

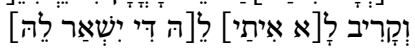

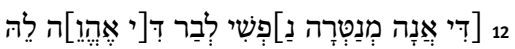

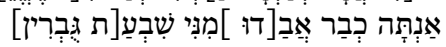

${ }_{10}[\ldots$ and she wept and went up] to the upstairs room of [her father's] house [... and desired to hang herself; ... It is better for me pray before the Lord ... [... and may I not hear a re]proach again in my lifetime.

${ }_{11}$ [And then she spread her hands] tow[ar]ds [the window and prayed: "Blessed are you, merciful God] and blessed are you and blessed] is your holy [and gl]orious name for e[ver, and] may [all your works (or: creations) bless [you.] ${ }_{12}$ [And now, t]o you [I have turned] my face towards you and I have [li]fted [my] eyes: and may you ordain that I may be freed from [the earth]

9 [and not return to hear reproaches. You, $\star \star \star \star$, kn] ow th[at] I am personally clean fr[om every impurity of a male, ${ }_{10}$ [and that] I [have not def]iled [my] na[me or] my [father's name] in all the land of our deportation; I am [my father's only daugh]ter, ${ }_{11}$ he has [no] other son to be [his] heir, nor has he a brother [or a] re[lative for whom] 12 [I should keep] my [so]ul, a son, for who[m I shall b]e a wife. Already seven [husbands] have peri[shed] on $\mathrm{me}^{29}$... LXX Tob 3:15-16 but if it please not thee that I should die, command some regard to be had of me, and pity taken of me, that I hear no more reproach. So the prayers of them both were heard before the majesty of God.

29 García Martínez/Tigchelaar, Dead Sea Scrolls, 385. 


\subsubsection{Tobit's prayer for death (Tob 3:1-6)}

This prayer has been not preserved among the Qumran Aramaic fragments and we can therefore present a translation based only on the Greek text. That it existed in Aramaic is certain, because we have fragments that precede Sarah's prayer for death, and are identical to Tobit's prayer.

${ }_{1}$ And I was much grieved in my soul and groaned and wept. 2 And I began to pray with groanings: O Lord, you are righteous, and all your works are righteous, and all your ways are mercy and truth: you judge the world. ${ }_{3}$ And now, O Lord, remember me, and look upon me; and take not vengeance on me for my sins, both for mine ignorance and my father's. 4 They sinned against you and disobeyed your commandments, and you gave us for spoil and captivity, and death, and for a proverb and a by-word and a reproach among all the nations among whom you had dispersed us. ${ }_{5}$ And now your many judgements are true in exacting from me the penalty of my sins, because we did not keep your commandments and walked not truly before you. ${ }_{6}$ And now deal with me according to your will, and command my spirit to be taken from me, that I may be released from off the earth and become earth: for it is more profitable for me to die than to live, because I have heard false reproaches, and there is much sorrow in me. Lord, command that I be released from this distress, let me go to the everlasting place, and turn not your face, O Lord, away from me. For it is more profitable for me to die, than to see much distress in my life, and not to hear reproaches. ${ }^{30}$

\subsubsection{Tobit's prayer in joy}

\begin{tabular}{|c|c|}
\hline $\begin{array}{l}\text { Greek, Hebrew and Aramaic medieval } \\
\text { fragments }\end{array}$ & $\begin{array}{l}\text { Tobit's praise for having been healed } \\
\text { Tob 11:14-18 }\end{array}$ \\
\hline 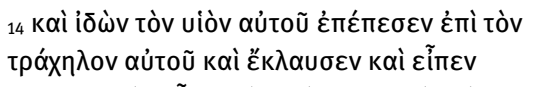 & $\begin{array}{l}{ }_{14} \text { Then he saw his son and put his arms } \\
\text { around his neck, and he wept and said to him, }\end{array}$ \\
\hline 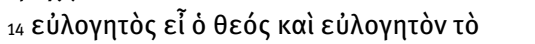 & “I see you,] my son, [the light of my eyes!” \\
\hline 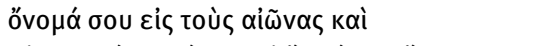 & sed (are you) O God, and \\
\hline 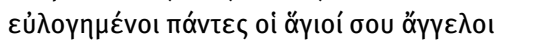 & blessed be your name for ever, and blessed be \\
\hline 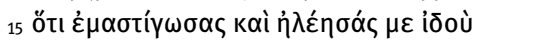 & 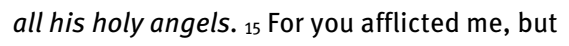 \\
\hline 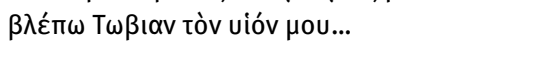 & $\begin{array}{l}\text { you had mercy upon me; here I see my son To- } \\
\text { bias!"... }\end{array}$ \\
\hline$\lambda \theta \varepsilon v \mathrm{Ta}$ & ${ }_{16}$ And Tobit went out to the gate of Nineveh to \\
\hline $\operatorname{vov} \mu \varphi$ & meet his daughter-in-law, rejoicing and bless- \\
\hline 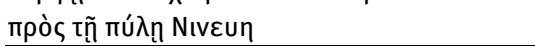 & ing God ... \\
\hline
\end{tabular}

30 Charles, Apocrypha (Tob 3:1-6). 


\section{Summarized features}

The above-mentioned prayers are all emotional prayers and are similar in structure and vocabulary. The first three are petitionary prayers and laments. The fourth is a praise. The proportion is significant. There are far more petitionary prayers than thanksgiving prayers or praises. They start with a description of the deep distress of a suffering individual who weeps and is depressed. The prayers open with blessings and praise of God, then move on to complaint, and end with a request addressed to God in a humble manner, "if it pleases God". The Lord's Prayer uttered by Jesus in Aramaic has exactly the same shape: introductory blessing, praise of God (and his great name), and the request (give us bread, forgive our sins). As with Tobit's prayer for death, the Lord's Prayer does not begin with a Berikh-formula, but starts with a praise of God's majesty and, as in the prayers of Tobit and Sarah, a request is moderated by a reformulation in which God is asked to act according to his will.

In the final part, the petitionary prayer awaits God's intercession: Tobit ends his prayer by telling God that he should be dealt with according to God's will but it would better for him to let him die; Sarah ends her prayer by asking God to hear her distress, if that is God's will. Abram's intercessory prayer ends with a request for God's justice.

The "solution", or God's answer to the request, is also similar here: God hears Abram's prayer, then afflicts the Egyptian court and strikes them with a fearful disease. As for Tobit's and Sarah's prayers for death, the biblical text itself states that: "At the self-same time the prayer of both was heard before the glory of God. And Raphael was sent to heal them both: in the case of Tobit to remove the blindness from his eyes, that he might see again the light of God with his eyes; and in the case of Sarah the daughter of Raguel, to give her for a wife to Tobias the son of Tobit, and to unbind Asmodaeus the evil demon from her ..." (Tob 3:16-17). ${ }^{31}$

The fourth example of Tobit's praise follows the same structure: blessing, praise, evocation of the reasons for the earlier lament, and a concluding thanksgiving and renewed blessing.

All these prayers are short and structured, following a common pattern in form and language. Judith Newman's general statement on Jewish prayers is also valid for these Qumran Aramaic texts: "There seems to be an increased

31 Charles, Apocrypha (Tob 3:15-17). 
occurrence of short blessings in the late literature which are uttered 'spontaneously' according to the narratives." 32

The praying person speaks in the first person ("I bless", "I pray", "I ask", "I entreat") and addresses himself to God in the second person ("Blessed are you"; "according to your will"). Women and men pray the same way and wait to be heard and rescued by God.

Prayers are ways of offloading one's mental ballast. For a time, the suffering person is delivered from his pain, as in the prayer of Abram about Lot and Sarah: it starts with bitter weeping, and ends with weeping followed by a deep silence. The prayers are emotional prayers and the emotion is an embodied feeling and thought that is expressed through physical postures and gestures, involving eyes, hands, lips, and sometimes even the whole body. In the Aramaic Qumran prayers, the preferred gesture is standing with outstretched hands and with eyes and face lifted towards God. Inside a house, the petitioner approaches the window before addressing his prayer to God (Tob 3:11). By raising the hands, the person who prays opens his heart to God who is in heaven, as is clearly expressed in Lam 3:41 (also Job 11:13; 2 Macc 3:20; 15:12, 21). ${ }^{33}$

\section{1 $B^{e}$ rikh-blessings in the Aramaic texts from Qumran}

As Esther Chazon has indicated, ${ }^{34}$ the Hebrew non-biblical scrolls from Qumran hardly attest to opening blessings with spontaneous personal expressions of supplication and petitional prayers. Also, there are few petitionary prayers among the Hebrew texts that are considered non-sectarian..$^{35}$ In contrast, the Aramaic scrolls, which are essentially narrative texts and without doubt nonsectarian, offer an important proportion of opening blessings, but do not attest to any final ones in Qumran Aramaic.

Among the Aramaic Qumran texts, we have at least six prayers starting with an opening $b^{e}$ rakha, which occurs in Aramaic with the passive $b^{e} r i k h$-formula "blessed" (hebr. barukh, gr. củ入oyntós) and once with the pael participle mbrk

32 Newman, Book, 27.

33 But even when the Israelites pray to God, as required, with stretched hands, God hears them only if they are free from sin, as is evident from Isa 1:15: "When you spread out your hands, I will turn my eyes away from you. Even multiply prayers, I will not listen. Your hands are filled with blood, your fingers with iniquity.”

34 Chazon, Dead Sea Scrolls, 158.

35 Cf. Schuller, Prayer (2000), 29-45, esp. 44. 
followed by the pronoun "you" in 1Q20 XX, 12. They all continue with a direct address to God "Blessed are you, o Lord/God of heaven and sky etc".

Whereas "the classic Hebrew formula brwk YHWH is completed by a relative clause "Blessed is/be the Lord, who ..." that details the particular divine action that gave rise to the speaker's gratitude", ${ }^{36}$ the Aramaic blessings from Qumran are not expanded by verbal relative clauses. The reason is that the petitionary prayers are not praising God for what has just happened, or what he has done for them, but expressing the wish and hope to be heard and helped after their statement of prayer and petition. Thus, the blessing is only a praise of God's majesty from whom the petitioner hopes to receive help. The blessing in the QA-prayers has no verb and is a simple nominative phrase, with no relative clause praising God's exaltedness as in the biblical and Hebrew liturgical blessings from Qumran. ${ }^{37}$

The $b^{e}$ rikh-formulas in the Aramaic prayers from Qumran are in general connected with weeping and rejoicing. For the Aramaic texts, see the prayers transcribed below, with the blessings in cursive script.

a. In pain in the Genesis Apocryphon (1Q20 XX, 12-14):

Abram wept bitterly ... 12 That night I praved, entreating and seeking mercy. And I said through sorrow and streaming tears. "Blessed are You, O God Most High, Eternal Lord, for You are Lord and Ruler over everything. You are Sovereign over all the kings of the earth having power to enact judgement on all of them". So now I lodge my complaint ...

b. In Sarah's prayer for death:

Tob 3:12-13 (4Q196 frag. 6, 10-11): "and she wept ... and prayed: Blessed are you, O merciful God, and blessed is your name for ever: and let all thy works bless you forever".

c. In Tobiah's joyful praise in Tob 8:15-17:

${ }_{15}$ And he blessed the God of heaven and said: ${ }_{16}$ "Blessed are you, O God, with all pure blessing; let them bless you forever. And blessed are you, because you made me glad: and it had not befallen as I supposed, but you dealt with us according to thy great mercy. ${ }_{17}$ And blessed are you, because you had mercy on two that are the only begotten children of their parents: showing them mercy and deliverance, O Lord; and you fulfilled their life with gladness and mercy."

36 Chazon, Dead Sea Scrolls, 155.

37 Cf. Chazon, Dead Sea Scrolls, 159-160. 
d. In Tobit's prayer of praise and joy in Tob 11:14-15:

"Blessed is God, and blessed is his great name, and blessed are all his holy angels. ${ }_{15}$ May his great name [ ] be blessed [ ] for all ages." And Tobias went in rejoicing and blessing God in his whole body.

Other blessings that stand outside a prayer context are to be found in the book of Enoch:

e. Enoch's blessing (4Q205 [En ${ }^{\mathrm{d}}$ ar] frag. $1 \mathrm{XI}, 2-3=1$ En. 22:14):

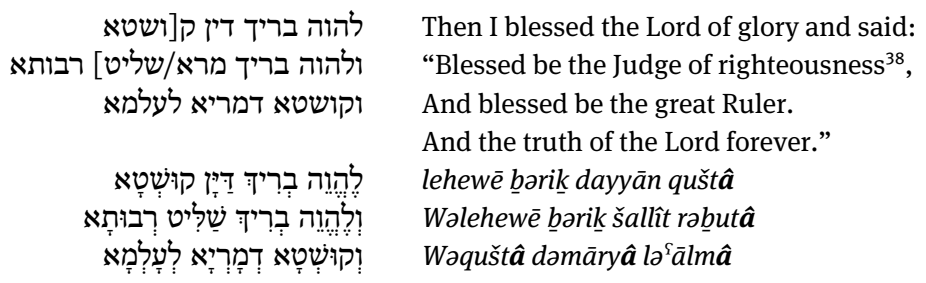

In the transliterated and vocalized Hebrew text we wish to demonstrate the stylistic features that characterize the blessing, that is, the syntagmatic repetition, synonymous parallelism, and final rhyme $-\hat{a} .{ }^{39}$

f. Qahat's testamentary instruction to his sons contains a hymnic praise that possibly opened with a $b^{e}$ rîkh-blessing as in other testamentary texts. It contains all that one needs for a liturgical $b^{e}$ rakha - and, interestingly, it is couched in Aramaic.

\begin{tabular}{|c|c|}
\hline $4 Q 542 \mathrm{I}, 1$ & 1,2 \\
\hline ס & $\circ$ [Blessed is the great God] \\
\hline 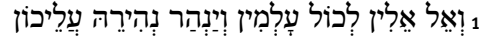 & 1 and God of gods for all the centuries. And he \\
\hline 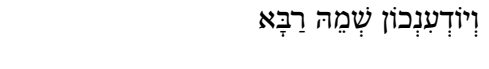 & $\begin{array}{l}\text { will make his light shine upon you and make } \\
\text { you know his great name }\end{array}$ \\
\hline
\end{tabular}

38 Or: "Blessed be the righteous judge, blessed be the great ruler and the righteousness of the Lord forever."

39 A poetic structure with rhyme and rhythm is also evident in the Genesis Apocryphon in the blessings of Abram and Melkizedek's blessing of Abram (1Q20 XXII, 16-17, see Gen 14:19-20):

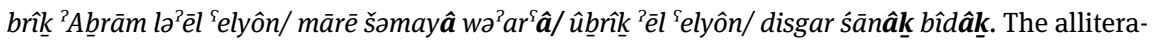
tion of $/ \mathrm{k} /$ and final $/ \mathrm{a} /$ helps to memorize such blessings more easily. In contrast, the Hebrew blessing parallelled by Gen 14:19-20 does not contain these features and is therefore not well designed for learning by heart. 


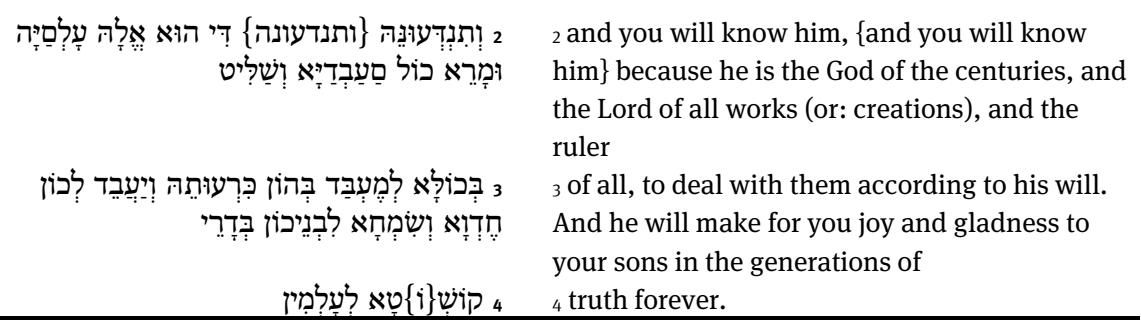

We observe in the Aramaic texts, more than in the Hebrew texts from Qumran, ${ }^{40}$ that the holy name of God is avoided and replaced. We never find the tetragrammaton, nor the title "God of Israel", but find instead many substitutions. ${ }^{41}$ God is called by epithets as, for instance: in the Tobit manuscripts the tetragrammaton is rendered by 4 dots and in the Daniel manuscripts we find the word 'elāhāk "your God", written in ancient Hebrew letters, due to the great respect being accorded to the title. Although ${ }^{2}$ elāhâ is well attested (39x, in biblical Aramaic texts of Qumran),42 even this title of God is avoided and divine titles and epithets are generally preferred instead, like: Great Name (šèm rabbâ), Almighty God ( ${ }^{2} E l{ }^{\complement}$ Elyon), Lord of Heaven ( $m \bar{a} r \bar{e}^{?} \check{s}^{e}$ mayya), Lord of Heaven and Earth; Lord of Eternity (māre $\bar{e}^{-}{ }^{\complement} \bar{a} l m a ̂$ and mare $\left.{ }^{\complement} \bar{a} l m a y y \hat{a}\right)$, Eternal King (melek $\check{s}^{e}$ mayyâ), the Great Holy One (qaddîša rabbâ), our Great Lord (māråna rabba) and Lord of Eternity (māre $\bar{e}^{\mathrm{S}} \mathrm{a}$ alma) in 4Q202En ${ }^{\mathrm{b}}$ ar 71, 14, and God is called "truth" or "justice" (qudšâ); see 1Q20 (1QapGen) "3 $^{3}$ and 4QQahat 1 I, 1-2. One of God's substitutions is found in compositions with the simple noun "name", a common substitute for the tetragrammaton in the rabbinic and Samaritan litera-

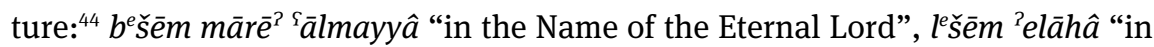
the Name of God" "45; and this divine "name" is sanctified in Tobit (4Q196 frag. 6, 7; frag. 18, 11), Enoch (reconstructed after the Greek, 4Q202 [En ${ }^{\mathrm{b}}$ ar] frag. 1, 15) and in the Lord's Prayer.

40 The tetragrammaton YHWH and the divine name EL are generally written in palaeoHebrew and so also in the LXX scroll from Nahal Hever (although the scroll is otherwise written in Greek, a feature which is still observed in Greek Bible manuscripts centuries later - even if penned by Christians. See more in De Troyer, Names (2006), 55-66; Williams, Interpretation, 66-68; Skehan, Name, 16-18; Parry, Notes; Stegemann, Erwägungen, 200-202.

41 See the detailed study of Bernstein, Titles, 291-310, esp. 295.

42 Only once attested in 1QapGen.

43 Cf. Greenfield, Contribution, 94 [488].

44 Cf. De Troyer, Names (2005).

45 Greenfield/Sokoloff, Qumran Aramaic, 92-94. 


\section{Summarized common features}

At the end of this presentation of selected Aramaic prayers from Qumran, we now wish to summarize similarities and common features starting with the prayer situation, the emotional state, the formal character of these prayers, and the significance of these similarities.

In the Aramaic Qumran prayers and berîkh formulas we find substitutes for God's name as a sovereign of the world, as ruler (šalliț), and sometimes as a king, which is the standard form that the rabbis required for a liturgical $b^{e}$ rakha and statutory private prayer (b. Ber. 40b). ${ }^{46}$

According to the rabbinical halakha, a berakha that does not contain God's name, or mention his kingship as a ruler of the universe, is not a valid one (b. Ber. 12a; 49a). ${ }^{47}$ Interestingly in this regard, the first part of the Lord's Prayer also has all the elements that a full berakha must contain. ${ }^{48}$ The liturgical $b^{e}$ rakha is often expanded by the words "do what you wish", or, "according to your will" or "may it be your will" as in Tob 3:6, and in the Testament of Qahat. In the text of Qahat 4Q542 frag. 1 I, 3 we have a kind of prayer, at least a praise, that contains features of a full $b^{e} r a k h a^{49}$ which means many epithets for God as God of Gods, Eternal God, Lord of all creations, Lord over all works, and Ruler over all. Unfortunately, since we do not have the complete text, we cannot be sure that the praise opened with a berakha. Stefan Reif's observation concerning the Hebrew Qumran prayers is also valid for the Aramaic prayers: "The Qumranic use of benedictions is not to be seen as a precedent for the later rabbinic employment of this genre. More accurately, the liturgical developments at Qumran should be plotted at a point between the biblical beginning and the rabbinic progression, that is close to the position occupied by the Apocryphal and Pseudepigraphical literature." 50

46 Cf. Heinemann, Prayer, 157.

47 This is also the ruling codified by Maimonides in Mishneh Torah, Ber. 1.5.

48 Cf. Schattner-Rieser, Aramäische.

49 Cf. Heinemann, Prayer, 162.

50 Reif, Problems, 44-45. 


\section{Conclusions}

Prayers fulfill an important task by helping individuals to manage negative and positive emotions. As a person prays, he can identify himself through the existing narratives, experiencing a similar feeling to that described in the texts, which will provide indirect and direct guidelines for the construction of his own prayer. Since personal prayers articulate all manner of feelings and emotions, a text serves as a guide or companion for the reader who can probably observe with more discernment his own parallel feelings. It is comforting for an individual to know that someone else has had the same feelings, and that another person has experienced similar situations. He thus helps himself to overcome his problems by addressing himself to God.

Prayers: 1. help individuals to deal with a particular type of emotion and have an appreciable influence on social action; they allow the worshipper: 2 . to interact with God face to face and: 3. they fulfill a didactic purpose, given that they teach individuals how to pray ${ }^{51}$, and how to address themselves to God in the appropriate way and language. Since the speech used in daily life, was Aramaic, it is clear from the texts discussed above that there was no restriction concerning its employment as an authorized language for liturgy, much as Hebrew. Another interesting feature is that there are no dualistic elements and that the $b^{e}$ rikh formula is on its way towards standardization. This, to our mind, supports the argument that the process did not start in the Exile but at the end of the Persian period.

S. Sharp may be summarized: In particular, interactions with God through prayer provide individuals with: (1) another to whom one can express and vent anger; (2) positive reflected appraisals that help maintain self-esteem; (3) reinterpretive cognitions that make situations seem less threatening; (4) another with whom one can interact to "zone out" negative emotion-inducing stimuli; and (5) an emotion management model to imitate. Most of these resources help individuals to begin to deal with a particular type of emotion and have an appreciable influence on social action. ${ }^{52}$

Even though the prayers in Qumran are presented as the spontaneous expressions of individuals, one may already notice the standardization of the $b^{e}$ rakha-formulations with regard to structure, form and style. ${ }^{53}$ Although all the

51 See also Böckler, Beten, 157-174.

52 Cf. Sharp, Prayer, 417-437.

53 Cf. Heinemann, Prayer, 80: A standard $b^{e} r a k h a$-formula has to include mentions of a divine title and divine kingship. 
wording in our corpus is not exactly identical, the content of the $b^{e}$ rakha-formulations shares common features with the later Hebrew $b^{e}$ rakha-formulations and statutory rabbinic prayers.

Prayers and blessings occupy a prominent place in the Aramaic texts from Qumran and serve as a medium by which humans communicate their joy and pain to God in the form of lament and praise, as well as praise and thanksgiving.

All the Aramaic prayers are inserted into narrative plots and in a sense function as school-texts for learning how to pray. They follow a well-defined pattern and have become a paradigm for petitioners who can read or hear these prayers and then express their own needs in the various circumstances of life in which they find themselves.

The individual who identifies himself with the fictional-person learns how to express his own experienced feelings and how to deal with his emotions.

Although there were no prayer books at that time and no authoritative prescriptions as how to pray, the records in those narratives contain structured features that undoubtedly served as guidelines for learning how to pray. ${ }^{54}$ Without setting down communal norms for individual piety, these texts with their wording and their gestures in various $b^{e}$ rakhot-formulas laid the basis for a kind of standard. The petitioner who respects the rules of prayer may be sure of a divine intervention that will help to deliver him from his misfortune. It is interesting to note that the prayer features and the openings of everyday blessings are in an Aramaic that undoubtedly belongs to the axial age..$^{55}$ All the examples discussed above represent the religious practices of the Second Temple period, and, together with the Lord's Prayer, contain formal liturgical elements.

According to Heinemann, ${ }^{56}$ individual prayers may be divided into three categories: 1 . The spontaneous prayer of the individual; 2. The routine prayer of the individual, although not statutory and 3. The statutory prayer of the individual.

54 In Ego/Merkel, Lernen, especially there: Böckler, Beten, 157-174.

55 In the rabbinical writings there are important discussions about whether it is permissible to pray in Aramaic. In b. Šabb. 12b and b. Soțah 33a it is said that personal petitions should rather be expressed in the holy tongue (lěšôn haq-qōdeš), Hebrew, rather than in Aramaic, for the angels do not understand Aramaic, with exception being made in the case of weak and sick persons. Even if the Sages gave preference to Hebrew for the language of prayer, there were defenders of the Aramaic language, which in any case was allowed for individual prayers, and for sick and weak people (y. Meg. 1.9, 71b; Esth. Rab. 4.12. If the Sages discussed the languages allowed for praying it proves that people prayed in their local languages, and one of those in the land of Israel at that time was Aramaic.

56 Heinemann, Prayer, 156. 
The similarities among the Aramaic Qumran prayers prove that they are situated at point two: routine prayers. Since these prayers and benedictions are written in classical Imperial Aramaic and belong to the third century BCE (with some Tobit and Enoch fragments even dating to the fourth century BCE!), one may conclude that already in late Persian times there was some "regulation" of individual prayers.

I would like to conclude with Stefan C. Reif's statement: "During the Second Temple period, the tendency developed to link the personal prayer and the formal liturgy. From the Apocryphal and Pseudepigraphical sources, it is apparent that there was an increasing number of benedictions, hymns and praises, mystical formulations of considerable variety ..." ${ }^{57}$

\section{Abstract}

Among the more than 900 Dead Sea scrolls there is a considerable number of prayers for specified occasions and these provide the earliest testimony of liturgical formulations of communal nature.

In addition to these official prayers, there exist personal prayers in Hebrew and Aramaic, which together amount to testimonies of private, apparently spontaneous expressions of supplications or thanksgiving from the Second Temple Period. Allocated first for private use, the formulations and gestures of individual prayers shifted later to a "fixed" or standard format, and included blessings in the common language: Aramaic.

This paper offers an overview of Aramaic prayers with standardized prayer $B^{e}$ rakhot-formulae and examines their function and didactic aims within the context of prayer in Second Temple Judaism around the life-time of Jesus.

57 Reif, Problems, 73. 


\section{Bibliography}

Arnold, R.Z.D., The Social Role of Liturgy in the Religion of the Qumran Community (STDJ 60), Leiden/Boston: Brill, 2006.

Bernstein, M., Divine Titles and Epithets and the Sources of the Genesis Apocryphon: JBL 128 (2009) 291-310.

Böckler, A.M., Beten als Lernen - Lernen als Mitzwa. Das Gebetbuch als Lehrbuch im Judentum, in: Ego, B./Merkel, H. (eds.), Religiöses Lernen in der biblischen, frühjüdischen und frühchristlichen Überlieferung (WUNT 180), Tübingen: Mohr Siebeck, 2005, 157-174.

Böttrich, Ch., Tempelmetaphorik „Ihr seid der Tempel Gottes“. Tempelmetaphorik und Gemeinde bei Paulus, in: Ego, B./Lange, A./Pillhofer, P. (eds.), Gemeinde ohne Tempel/Community without Temple (WUNT 118), Tübingen: Mohr Siebeck, 1999, 411-425.

Charles, R.C.H., Apocrypha of the Old Testament, Electronic version; Bellingham, WA: Logos Bible Software 2004.

Charlesworth, J./Newsom, C.A. (eds.), Angelic Liturgy: Songs of the Sabbath Sacrifice (PTSDSSP), Tübingen: Mohr Siebeck, 1999.

Chazon, E.G., Looking Back. What the Dead Sea Scrolls Teach Us about Biblical Blessings, in: David, N./Lange, A. et al. (eds.), Hebrew Bible in Light of the Dead Sea Scrolls (FRLANT 239), Göttingen: Vandenhoeck \& Ruprecht, 2012, 155-171.

Chazon, E.G., Liturgy before and after the Temple's Destruction: Change or Continuity?, in: Schwartz, D.R./Weiss, Z. (eds.), Was 70 CE a Watershed in Jewish History? On Jews and Judaism before and after the Destruction of the Second Temple (AGJU 78), Leiden: Brill, 2012, 371-392.

Chazon, E.G., Prayers from Qumran and Their Historical Implications: DSD 1 (1994) 265-284.

Chazon, E.G./Pinnick, A., Liturgical Perspectives: Prayer and Poetry in Light of the Dead Sea Scrolls. Proceedings of the Fifth International Symposium of the Orion Center for the Study of the Dead Sea Scrolls and Associated Literature, 19-23 January 2000 (STDJ 48), Leiden: Brill, 2003.

De Troyer, K., On Names of God: Journal of the European Society of Women in Theological Research 14 (2006) 55-68.

De Troyer, K., The Names of God. Their Pronunciation and Their Translation. A Digital Tour of Some of the Main Witnesses: Lectio Difficilior 2 (2005) <http://www.lectio.unibe.ch/05_2 /troyer_names_of_god.htm>

Di Lella, A., Two Major Prayers in the Book of Tobit, in: Egger-Wenzel, R./Corley, J. (eds.), Prayer from Tobit to Qumran (DCLY 2004), Berlin/New York : De Gruyter, 2004, 95-115.

Dimant, D., 4QFlorilegium and the Idea of the Community as a Temple, in: Caquot, A. et al. (eds.), Hellenica et Judaica, FS V. Nikiprowetzky, Leuven/Paris: Peeters, 1986, 165-189.

Egger-Wenzel, R./Corley, J. (eds.), Prayer from Tobit to Qumran (DCLY 2004), Berlin/New York: De Gruyter, 2004.

Ego, B./Merkel, H. (eds.), Religiöses Lernen in der biblischen, frühjüdischen und frühchristlichen Überlieferung (WUNT 180), Tübingen: Mohr Siebeck, 2005.

Elbogen, I., Der jüdische Gottesdienst in seiner geschichtlichen Entwicklung, Frankfurt: Kaufmann, 1931 (reprint, Hildesheim: Olms, 1962).

Falk, D.K., Daily, Sabbath, and Festival Prayers in the Dead Sea Scrolls (STDJ 27), Leiden: Brill, 1998. 
Fitzmyer, J.A., The Genesis Apocryphon of Qumran Cave 1 (1Q20): A Commentary (BibOr 18B), Roma: Pontificio Istituto Biblico, 32004.

Gärtner, B., The Temple and the Community in Qumran and the New Testament: A Comparative Study in the Temple Symbolism of the Qumran (SNTSMS 1), Cambridge: Univ. Press, 1965.

García Martínez, F./Tigchelaar, E.J.C., The Dead Sea Scrolls Study Edition, 2 vols., Leiden: Brill, 1997-1998.

Gaster, M., Two Unknown Hebrew Versions of the Tobit Legend: PSBA $18+19(1896+1897)$ 208, 22, 259-271 + 27-38 (reprint in: Gaster, M., Studies and Texts in Folklore, Magic, Mediaeval Romance, Hebrew Apocrypha, and Samaritan Archaelogy, 3 vols., London: Maggs, 1925-1928; reprint with prolegomenon by Gaster, T., New York: Ktav, 1971).

Greenfield, J.C., Contribution of Qumran Aramaic, in: Paul, S.M./Stone, M.E./Pinnick, A. (eds.), Al Kanfei Yonah. Collected Studies of Jonas C. Greenfield on Semitic Philology, 2 vols., Leiden: Brill/Jerusalem: Magnes, 2001.

Greenfield, J.C./Sokoloff, M., Qumran Aramaic, in: Muraoka, T. (ed.), Studies in Qumran Aramaic (AbrNSup 3), Leuven: Peeters, 1992, 92-94.

Hammer, R., Entering Jewish Prayer. A Guide to Personal Devotion and the Worship Service, New York: Schocken Books, 1994.

Heinemann, J., Prayer in the Talmud (SJ 9), Berlin/New York: De Gruyter, 1977.

Hogeterp, A.L.A., Paul and God's Temple. A Historical Interpretation of Cultic Imagery in the Corinthian Correspondence (BTS 2), Leuven: Peeters, 2006.

Idelsohn, A.Z., Jewish Liturgy and Its Development, New York: Holt, 1932.

Lockyer, H., All the Prayers of the Bible, Grand Rapids, MI: Zondervan, 1959.

McDowell, M., Prayers of Jewish Women: Studies of Patterns of Prayer in the Second Temple Period (WUNT II/211), Tübingen: Mohr Siebeck, 2006.

Machiela, D.A., The Dead Sea Genesis Apocryphon: A New Text and Translation with Introduction and Special Treatment of Columns 13-17 (STDJ 79), Leiden: Brill, 2009.

Newman, J.H., Praying by the Book: The Scripturalization of Prayer in Second Temple Judaism (EJL 14), Atlanta, GA: Scholars Press, 1999.

Newsom, C.A., Songs of the Sabbath Sacrifice, in: Kiley, M. (ed.), Prayer from Alexander to Constantine: A Critical Anthology, London: Routledge, 1997, 28-32.

Nitzan, B., Qumran Prayer and Religious Poetry (STDJ 12), Leiden: Brill, 1994.

Parry, D.W., Notes on Divine Name Avoidance in Scriptural Units of Legal Texts of Qumran, in: Bernstein, M. et al. (eds.), Legal Texts and Legal Issues: Proceedings of the Second Meeting of the International Organization for Qumran Studies 1995, FS J.M. Baumgarten (STDJ 23), Leiden: Brill, 1997, 437-449.

Reif, S.C., Judaism and Hebrew Prayer: New Perspectives on Jewish Liturgical History, Cambridge: Univ. Press, 1993.

Reif, S.C., Prayer in Early Judaism, in: Egger-Wenzel, R./Corley, J. (eds.), Prayer from Tobit to Qumran (DCLY 2004), Berlin/New York: De Gruyter, 2004, 439-466.

Reif, S.C., Problems with Prayer: Studies in the Textual History of Early Rabbinic Liturgy (SJ 37), Berlin/New York: De Gruyter 2006.

Reif, S.C., The Second Temple Period, Qumran Research and Rabbinic Liturgy: Some Contextual and Linguistic Comparison, in: Chazon, E.G./Pinnick, A. (eds.), Liturgical Perspectives: Prayer and Poetry in Light of the Dead Sea Scrolls. Proceedings of the Fifth International Symposium of the Orion Center for the Study of the Dead Sea Scrolls and Associated Literature, 19-23 January 2000 (STDJ 48), Leiden: Brill, 2003, 133-149. 
Sarason, R.S., Communal Prayer at Qumran and among the Rabbis: Certainties and Uncertainties, in: Chazon, E.G./Pinnick, A. (eds.), Liturgical Perspectives: Prayer and Poetry in Light of the Dead Sea Scrolls. Proceedings of the Fifth International Symposium of the Orion Center for the Study of the Dead Sea Scrolls and Associated Literature, 19-23 January 2000 (STDJ 48), Leiden: Brill, 2003, 151-172.

Schattner-Rieser, U., 'UŠ (אושט). From the Foundation of the Temple to the Foundation of a Community: On the Semantic Development from Aramaic to Hebrew אוש "Community Foundation, in the (Hebrew and Aramaic) Dead Sea Scrolls", in: Fassberg, S.E./Bar-Asher, M./Clements, R.A. (eds.), Hebrew in the Second Temple Period. The Hebrew of the Dead Sea Scrolls and of Other Contemporary Sources (STDJ 108), Leiden: Brill 2013, 214-225.

Schattner-Rieser, U., L'apport de la philologie araméenne et l'interprétation des archaïsmes linguistiques pour la datation des textes araméens de Qumrân, in: Berthelot, K./Stökl Ben Ezra, D. (eds.), Aramaica Qumranica: Proceedings of the Conference on the Aramaic Texts from Qumran in Aix-en-Provence 30 June - 2 July 2008 (STDJ 94), Leiden: Brill, 2010, 101123.

Schattner-Rieser, U., Das Aramäische zur Zeit Jesu und das Vaterunser. Reflexionen zur Muttersprache Jesu anhand der Texte von Qumran und der frühen palästinischen Targumim, in: Frey, J./Popkes, E.E. (eds.), Jesus, Paulus und Qumran (WUNT II), Tübingen: Mohr-Siebeck, 2015 (forthcoming).

Schattner-Rieser, U., Levi in the Third Sky. Traditions about the Ascent into Heaven Legends in Their Near Eastern Context, in: Lange, A. (eds.), The Dead Sea Scrolls in Context. Integrating the Dead Sea Scrolls in the Study of Ancient Texts, Languages, and Cultures (STDJ 11), Leiden: Brill, 2011, 801-819.

Schattner-Rieser, U., "L'apport de la philologie araméenne et l'interprétation des archaïsmes linguistiques pour la datation des textes araméens de Qumrân”, in : Berthelot, K./Stökl Ben Ezra, D. (eds.), Aramaica Qumranica: The Aix en Provence Colloquium on the Aramaic Dead Sea Scrolls (STDJ 94), Leiden: Brill, 2010, 101-123.

Schelbert, G., ABBA. Stand der Frage: FZPhTh 40 (1994) 259-281.

Schelbert, G., Abba, Vater. Der literarische Befund vom Altaramäischen bis zu den späten Midrasch- und Haggada-Werken in Auseinandersetzung mit den Thesen von Joachim Jeremias (NTOA 81), Göttingen: Vandenhoeck \& Ruprecht, 2011.

Schuller, E., Some Observations on Blessings of God in Texts from Qumran, in: Attridge, H.W./ Collins, J.J./Tobin, T.H. (eds.), Of Scribes and Scrolls: Studies on the Hebrew Bible, Intertestamental Judaism and Christian Origins, FS J. Strugnell (Resources in Religion 5), Lanham, MD et al.: Univ. Press of America 1990, 133-143.

Schuller, E., Prayer at Qumran, in: Egger-Wenzel, R./Corley, J. (eds.), Prayer from Tobit to Qumran (DCLY 2004), Berlin/New York: De Gruyter, 2004, 411-428.

Schuller, E., Petitionary Prayer and the Religion of Qumran, in: Collins, J.J./Kugler, R.A. (eds.), Religion in the Dead Sea Scrolls (Studies in the Dead Sea Scrolls and Related Literature), Grand Rapids, MI: Eerdmans, 2000, 29-45.

Sharp, S., How Does Prayer Help Manage Emotions? Social Psychology Quarterly $73 / 4$ (2010) 417-437.

Skehan, P.W., The Divine Name at Qumran, the Masada Scroll and in the Septuagint: BIOSCS 13 (1980) 14-44.

Stegemann, H., Religionsgeschichtliche Erwägungen zu den Gottesbezeichnungen in den Qumrantexten, in: Delcor, M. (ed.), Qumrân: Sa piété, sa théologie et son milieu (BETL 46), Paris-Gembloux: Duculot, 1978. 
Stemberger, G., Gottesnamen. Altes Testament und Judentum, in: LTK 4 (1995) 936-938.

Stuckenbruck, L.T., The Book of Tobit and the Problem of "Magic", in: Lichtenberger, H./Oegema, G.S. (eds.), Jüdische Schriften in ihrem antik-jüdischen und urchristlichen Kontext (Studien zu den jüdischen Schriften aus hellenistisch-römischer Zeit 1), Gütersloh: Gütersloher Verlagshaus, 2002, 258-269.

Weeks, S./Gathercole, S./Stuckenbruck L. (eds.), The Book of Tobit: Texts from the Principal Ancient and Medieval Traditions with Synopsis, Concordances, and Annotated Texts in Aramaic, Hebrew, Greek, Latin, and Syriac (FSBP 3), Berlin/New York: De Gruyter, 2004.

Williams, C.H., I am He: The Interpretation of "anî Hû" in Jewish and Early Christian Literature (WUNT II/113), Tübingen: Mohr Siebeck, 2000.

Zgoll, A., Der betende Mensch. Zur Anthropologie in Mesopotamien, in: Janowski, B./Liess, K. eds.), Der Mensch im Alten Israel. Neue Forschungen zur alttestamentlichen Anthropologie (Herders Biblische Studien 59), Freiburg: Herder, 2009, 121-140. 